\title{
THE SUEZ CRISIS OF 1956 AND 1957 IN WEST GERMAN TELEVISION NEWS
}

\author{
Sigrun Lehnert \\ Independent researcher \\ sigrun.lehnert@freenet.de
}

\begin{abstract}
From the mid-1950s onwards, the number of television viewers in West Germany increased rapidly and television became the "window to the world" for many people. Through audio-visual reporting the people were informed so that they could feel safe as they know what had happened in the world, especially in times of the Cold War. The Suez Crisis of 1956/1957 was one of the Cold War conflicts that television was able to report on continuously and thus demonstrate its advantages. The Suez Crisis has to be considered not only in the context of the larger, geopolitical conflict between East and West, but also in a decolonization context, and it affected the Federal Republic of Germany (FRG) in several ways. The daily newscast Tagesschau, and the weekly compilation Wochenspiege/ was able to convey images from a distant region with high actuality. In the beginning, Tagesschau used material from the cinema newsreel and followed its style, but the news editors very soon developed their own strategies of modern reporting. This article outlines the style of West German television news in the 1950s as well as the routines and ways of reporting, which continue in news production today.
\end{abstract}

Keywords: West German television news, television history, Tagesschau, Wochenspiegel, Suez Crisis, 1950s

\section{Introduction}

The medium of television was "ramped up" in the 1950s from an experimental program to a mass medium ${ }^{1}$ and it became an "everyday event." In world-shaking times of crises, such as those triggered by the Suez conflict of 1956/1957, new media can prove themselves and their advantages and set themselves apart from established media. In the case of the West German audio-visual informational media, some continuities from the cinema newsreel to television news can be recognized. In some cases, newsreel cinematographers filmed for the television or newsreel cinematographers changed to television stations (Jan Thilo Haux, among others) ${ }^{3}$. Until 1955, television news ${ }^{4}$ used film material from the cinema newsreel Neue Deutsche Wochenschau (NDW), but then it was able to fill the programs 
independently and develop its own style and standards for continuous and rapid reporting. Editor in Chief Martin S. Svobodas' mission statement was: "Aktuell + schnell = Tageschau" [up-to-date and fast = Tagesschau]. ${ }^{5}$ In contrast to the cinema newsreels, the television news did not consist solely of edited film, but was broadcasted live. The new way of production was favoured by technical innovations, e.g. using $16 \mathrm{~mm}$ film (instead of $35 \mathrm{~mm}$ cinema format) and the use of hand cameras and other portable equipment. This had an impact on the style of reporting (e.g. becoming more spontaneous and flexible).

Additionally, the influence of the Western Allies on the West German media after the Second World War led to a new understanding of reporting and it was agreed that it should be neutral and objective. In contrast to the newsreel, the television news had little commentary and was not designed to impress the audience (as was appropriate in the cinema dispositive). On the other hand, in the 1950s the Tagesschau continued to use background music. Like in the newsreels, in the television news the music was used to dramatize. The first editor in chief of the Tagesschau said: "Musik treibt" [Music drives]. ${ }^{6}$ Viewers appreciated the television from the very beginning, because it was no longer necessary to leave the house to be informed by the newsreel at the cinema. According to a survey conducted by the Institut für Demoskopie in Allensbach [Allensbach Institute for Public Opinion Research] in 1956, most people who owned television set bought it in $1955 .{ }^{7}$ The viewers were satisfied with the information offered, particularly with the information they received through the Tagesschau. ${ }^{8}$ The importance of television continued to grow to be a 'Welterklärer' [explainer of the whole world]. This was also achieved through the expansion of the network of correspondents (e.g. Hans Wilhelm Vahlefeld and Peter von Zahn were first correspondents $)^{9}$ and cooperations with news agencies, such as Telenews and United Press (UP). ${ }^{10}$ An agreement on the mutual exchange of BBC and newsreel material had existed since $1953 .{ }^{11}$ In 1956 , the Tagesschau became a brand name and was given an unmistakable signature tune, which can still be heard in its modern variation today. ${ }^{12}$

News media support the public in opinion-building and in times of crisis, especially, they can develop or expand on qualities such as reducing complexity, objectivity, topicality, transparency/reflexivity and originality. ${ }^{13}$ The reporting on the Suez Crisis of 1956/1957 is a good example of this. It was a crisis, during which the world "held its breath," as the Tagesschau put it, ${ }^{14}$ because the Cold War between the great power blocs threatened to become 'hot' - and moreover - develop into a nuclear war. The divided Germany formed a front line between the East and the West. The Federal Republic of Germany (FRG) was affected by the Suez conflict in several ways, since all of the Allied states, that had shaped Germany and the lives of its citizens in its two states after the Second World, were involved. The Tagesschau and Wochenspiegel reported about the conflict as neutrally as possible with pictures showing several aspects of the situation.

"Nothing new at the Suez Canal" was the title of a Tagesschau report in September $1956 .{ }^{15}$ The choice of that title might be astonishing, but it underlines the similarity to today's news: ongoing reporting meant to inform, even when there is nothing special to report about. And when there is nothing to report about, reporters often report about themselves. The pictures display journalists taking interviews with bystanders and other reporters on the spot (see Figure 1) and waving to ships passing through the canal. Two reporters are driving in a car, which might be a taxi, along the beach promenade and following the ships. The camera shows the view through the car's windscreen (see Figure 2) and the car window frames are recognizable as well as a Rosary is hanging in the rear-view mirror. Due to these details, the spectator has the feeling that they are accompanying the reporters on this ride. Outside, everything appears to be calm, but a certain tension of a looming war is in the air. 

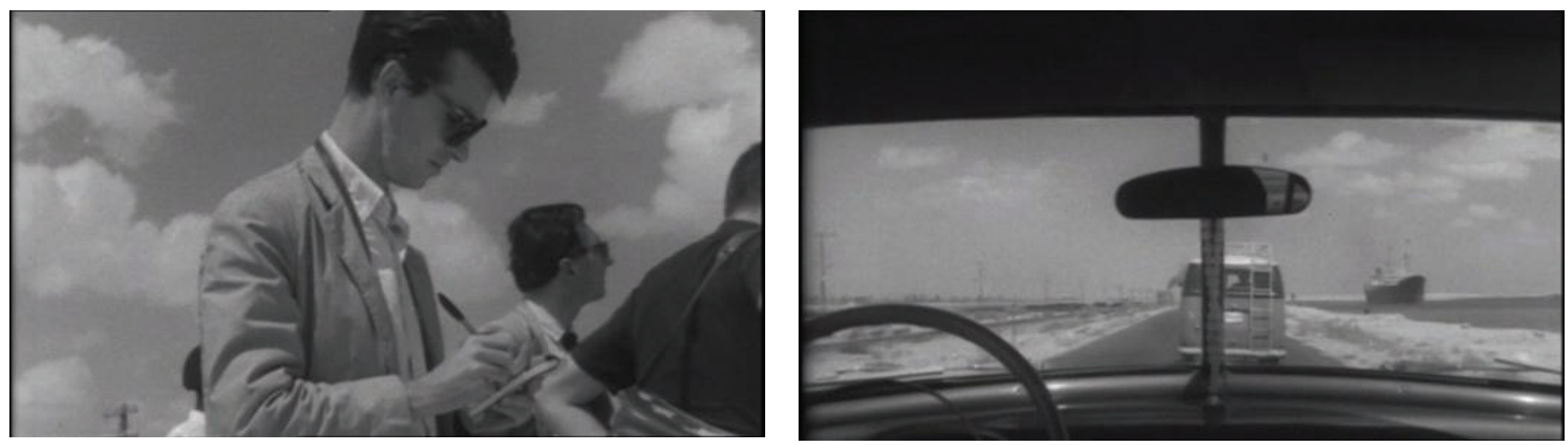

Figures 1 and 2. Journalists report: Nothing new at Suez Canal.

\section{West German Television News}

Before television was established in Germany, news was conveyed through the cinema newsreel ${ }^{16}$ - in the 1950 s, television news developed and was broadcast parallel to the cinema newsreel. The first edition of the post-war newsreel production Neue Deutsche Wochenschau (NDW) was presented in cinemas on the 3 February 1950. Television in West Germany began with a test screen broadcast in July 1950 by NWDR - and at the end of 1952, the official news program began. The newscast Tagesschau started on 26 December 1952. Not much later, on 4 January 1953, a weekly newscast named Wochenspiegel was broadcast for the very first time. Wochenspiegel was a weekly compilation of Tagesschau reports completed with the latest news and was arranged by the same editorial team. In the beginning, the concept for Tagesschau was in some points very similar to the newsreel Neue Deutsche Wochenschau. ${ }^{17}$ This is because up until March 1955, Tagesschau bought films (for about two Deutschmark per meter) from the Hamburg-based newsreel company Neue Deutsche Wochenschau GmbH and used them in the newscasts. It needs to be noted, though, that these newsreel-editions never replaced the Tagesschau broadcast, except in one single case, when there was not enough new material available - but this programme eventually failed according to the editing teams' professional standards and expectations, which had already changed. Background music, sound and comments were used in Tagesschau - but in a different way than in Neue Deutsche Wochenschau (more details follow). As usual in newsreels, each Tagesschau-newscast contained at least one entertaining, light and cheerful story - usually towards the end of the show. ${ }^{18}$

In this way, Tagesschau adopted some strategies from newsreels which were popular among spectators and which were used in the earlier cinematic news format too. The unbeatable advantages of Tagesschau however, were live broadcasting and actuality - although up until October 1956 Tagesschau new editions were only broadcast three times a week (on Monday, Wednesday and Friday; on the other days of the week repetitions were transmitted). But starting 1 October 1956, the newscast was scheduled every day (except on Sundays). This means that the technical requirements, e.g. switching from one television station to another in the time of seconds, ${ }^{19}$ were set up at the right time to reach many West German viewers with the most recent news about current affairs and worldwide conflicts (as it was for the Suez Crisis and the Hungary Conflict). The people in the FRG were touched by the riots in Hungary as - having had the same experience - many of them could identify themselves with the Hungarian expellees.

On Sundays, the TV program contained a weekly edition of the Wochenspiegel as a reproduction of a selection of Tagesschau-reports, complemented by the latest reports the editorial department had gained since the last Tagesschau show. Both newscasts addressed the audience directly, e.g. through the use of a more moderate voice (not in the shouting newsreel voice style). This fitted very well to the housing situation of the 1950s as television promoted a trend to stay at home in the newly built homes after the war and watch pictures of the world through the 
'window' of television. The number of television viewers increased rapidly from the mid-1950s and at the end of 1955 , the count was at about 250,000 viewers, at the end of 1956 numbers soared to about 600,000 viewers and, in October 1957, further increased to one million viewers. ${ }^{20}$

The 1956 research by Allensbach Institute for Public Opinion Research shows that only $28 \%$ of viewers had never watched television before (i.e. in the homes of friends or relatives, in restaurants, in shop windows). Only $3 \%$ of those who had watched television had their own television set, $47 \%$ watched in a restaurant and $22 \%$ watched television in a shop window. ${ }^{21}$ Hans-Joachim Reiche, author and editor of the ARD broadcasting corporations since 1949, stated: "Television allows viewers to evaluate processes in a way they have never seen before and makes it easier for them to comment". ${ }^{22}$ Young people in particular could form new political views by developing an understanding of the world first. The television experience became a natural part of the world view. ${ }^{23}$ The survey showed that young and middle-aged people were particularly interested in the television offer, especially families $(79 \%$ of them were married). It is interesting that those who did not have a high school education were particularly fascinated by television ( $63 \%$ had elementary school diploma, they were workers, employees, self-employed). ${ }^{24}$ Regarding the assessment of the role of the USSR, $40 \%$ of the respondents understood the caricature right and $19 \%$ misunderstood it completely (see Figure 3 ). ${ }^{25}$

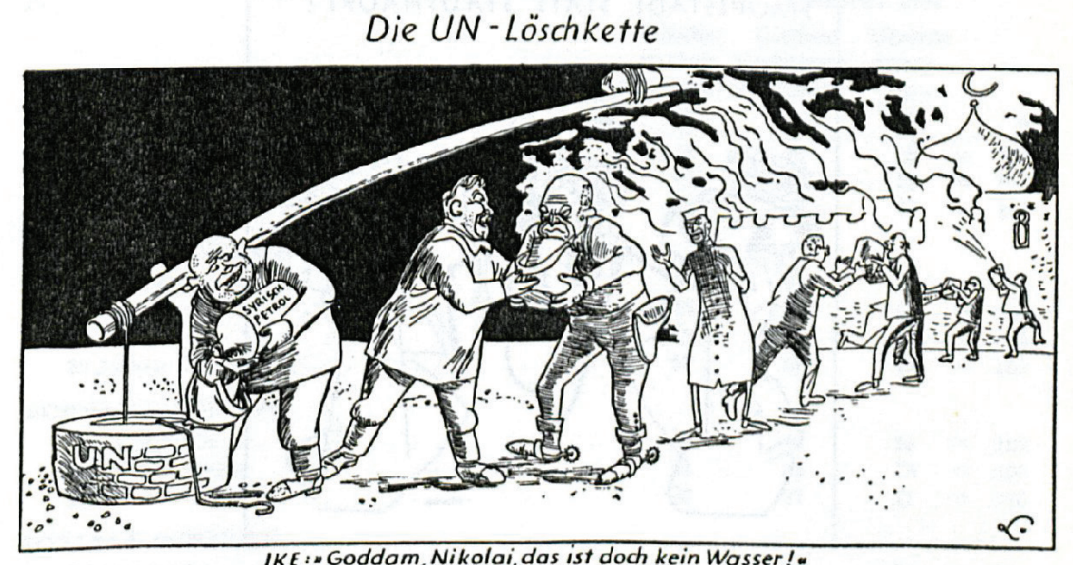

Figure 3. Caricature presented in a 1956 public opinion survey [Goddamn it, Nikolai, that isn't water!].

In the 1950s and 1960s, the news was increasingly expected to be objective. The news editor had to be "cool and dispassionate" without being guided by personal opinion. The "decisive prerequisite" refers to the independence of the news editor. His task is to reflect on events from around the world "especially political events, but not to make politics." 26 The editor-in-chief of the Tagesschau in 1960, Hans-Joachim Reiche, describes the progress like so: "With the introduction of television news, a new style of news has developed: the film, the photo, the graphics on the screen opened up new perspectives that only television can offer."27

\section{6 - The Year of Crises}

The so-called Suez Crisis was a military confrontation in 1956 between Egypt on one side, and Britain, France and Israel on the other side. ${ }^{28}$ Because of the struggle for Eastern or Western dominance in the Middle East, the superpowers of the USA and the Soviet Union also intervened. The interest of Britain and France in the Suez Canal goes back to the foundation of the French "Compagnie universelle du canal maritime de Suez" [Suez Canal Association], which financed the building of the strategically important canal (completed in 1869). Egypt's government held extensive shares - but due to national debt, Ismail Pasha, Viceroy of Ottoman province Egypt, had to sell a large 
packet of shares to Britain. As a consequence, Egypt became virtually a British protectorate. After Egypt's independence, however, the association was still under the influence of Britain and France as Arab oil became an outstanding economic importance for Europe. The Suez Canal was (and still is) an important shipping lane for goods and oil. It provides a direct connection to the Arab States, India, and other far away countries. The alternative way around the Cape of Good Hope was much more dangerous, time consuming, and therefore more expensive to use. European parties still held the free trafficking rights for the canal. After the toppling of King Farouk in July 1952, Gamal Abdel Nasser got into power. ${ }^{29}$

Nasser's goal was to improve Egypt's economic situation and raise the people's standard of living. The Aswan Dam was intended to secure the electricity and water supply in the underdeveloped country. The World Bank, led by the USA, had initially pledged funds, but then withdrew when it became known that Nasser had obtained Soviet weapons in response to Israeli armament (Israel was able to buy weapons from France). Under the Cold War, Nasser thus came under suspicion as the Western powers suspected him of having switched to the communist side..$^{30}$

In order to finance the construction of the Aswan Dam, Nasser decided to nationalize the canal on July 26,1956 . In this way, the income from the canal business would no longer go to the major shareholders (primarily England and France), but to Egypt. It would also be a step toward the country's final liberation from the colonial power of England. Great Britain again mobilized the troops that had been withdrawn shortly before, since access to the strategically important canal was considered to be endangered. At a conference in London in August 1956, which Germany also participated in, a common international administration was agreed upon. Nasser didn't agree to this, and, as a result 27 of the 205 pilots of the canal company (including British and French pilots) refused to serve. Since navigation on the canal is impossible without pilots, pilots (from Egypt, the Soviet Union and other countries, among others) had to be trained quickly and put in place to maintain operations. Germans who were qualified as pilots also volunteered, and they were offered a high salary. ${ }^{31}$ The USSR offered to secure the financing of the Aswan Dam and became an ally, the USA withdrew because they believed that Egypt was already 'lost' to the Soviet Union.

The Suez War began on October 29, 1956. Israel was persuaded by France and Great Britain to attack Egypt and occupied the Sinai Peninsula. France and Britain attacked Egypt because Nasser (as assumed) rejected an ultimatum for Egyptian-Israeli negotiations. In November, Port Said was occupied with the intention that the Egyptian people would overthrow Nasser - but the people stood behind their head of state. Nasser sunk ships in the channel to stop the troops. ${ }^{32}$ Because France and Britain knew that the USA would refuse to attack (as President Eisenhower would not risk his re-election) they excluded the USA from their secret plans against Egypt. But they underestimated the American interests in Egypt as a political and trade partner (in the rivalry with Soviet Union). This was the first misconception. The second misconception was their underestimation of the Soviets. The Soviet Union used its invasion in Hungary to set an ultimatum: Either London and Paris withdraw, or Hungary would be levelled to the ground. ${ }^{33}$ The USSR wanted to demonstrate that it is still powerful and threatened a nuclear war. The USA mobilized troops in response. Finally, only one solution was possible - pressure from the United States and the USSR at the United Nations forced the Allies to withdraw. ${ }^{34}$ This was followed by the invasion of UN soldiers into Egypt and all military actions were stopped. Britain and France withdrew again, Israeli soldiers left parts of Sinai. By March 1957, ships were able to pass through the Suez Canal again, including oil tankers, and the price of gasoline fell again. Nasser emerged stronger from the Suez crisis, was able to build the dam and help Egypt to greater prosperity. The Suez crisis was the last step towards the decolonization of Egypt. ${ }^{35}$

In the Suez Crisis matter, it was difficult for the Federal Republic of Germany (FRG) to find an appropriate position. The special relationship to Israel made it difficult to take party on one side. Because of the systematic annihilation of Jews in Nazi Germany, the Federal Republic of Germany was expected and felt the need to support the formation of an independent Israeli nation. Additionally, West Germany wanted to prevent the recognition of the other socialistic German state, the German Democratic Republic (GDR) by Egypt, as Egypt seemed to be associated with the USSR. ${ }^{36}$ The FRG was obligated to Great Britain, France and USA (former Allies) and needs the oil in the economic resurgence (so called 'economic miracle'). West Germany intervenes in diplomatic negotiations (International Suez Conference, 22 countries, August 1956 in London) and wants to be a member of the community of states for achieving a new 
position with a good image. So, two ships came from Hamburg for the clearance work in the Suez Canal. The incidents in the Middle Eastern states, marked by self-liberation and the Cold War, made it very important for Germans to receive information about the outcome of negotiations in the fighting nations.

\section{Suez Crisis News Reports: Characteristics}

The characteristics of the news reports can be separated into the following categories: text, structure and topics, of visual aesthetics, and of sound. In regard to the audiences' reception of those reports, one has to keep in mind that texts were read by an off-stage presenter (invisible for the audience), while film snippets, stills and location maps appeared on the television screen. ${ }^{37}$ Secondly, one has to keep in mind that almost all film material about the Suez Crisis was provided by the international picture agencies UP and Telenews; ${ }^{38}$ but the Tagesschau team did the final editing of all material delivered. So, it was they who were ultimately responsible for the selection and appropriate combination of visual material on the Suez Crisis.

Some remarks regarding the research conditions and the quality of the archive material: Although the full texts (original news scripts) of each Tagesschau are available in the archives not all films have been preserved. But in those cases when the films have been preserved, it is possible that a piece with pictures was removed from the tapes for later use in the Wochenspiegel, and just black film remained instead. Since most material at the time consisted of silent film, Tagesschau had to add extra sound in the moment of live broadcasting, as distinct from the newsreels' complete film material, which was delivered to cinemas. On the whole, the music tracks used in television news have not been preserved, but the pictures have - and sometimes vice versa. Due to the lack of appropriate recording techniques, the newsreader's voice has not been preserved - although, in some cases, the voiceover can be heard in Wochenspiegel shows.

In the following, the characteristics of the components - as introduced in the above paragraph as text, structure of reports, topics, and films - will be outlined:

i. Text: One special way to involve the viewers in front of the television screen, which also helped to create a form of suspense, was the use of rhetorical questions such as: "Will there be war?" or "What will happen to the prisoners of war?"39 But there is no added drama or direct reference to the Cold War and the tensions between the world powers of the Soviet Union and the USA. Despite the lack of time for careful editing (in the manner of the cinema newsreels), the texts of Tagesschau were revised by the presenter during the last minutes before the broadcast started, as can be seen in the corresponding text sheets, which show final corrections made by the presenter.

ii. Structure: At the beginning of the crisis, and during its peak, corresponding stories were mostly shown first and used as lead stories. Particularly those stories with news regarding UN and UNO activities, or news about German support attempts such as that of the dispatch of two ships, named "Energie" [power] und "Ausdauer" [endurance], which were sent to the Suez Canal to remove wreckage. But, as of March 1957, the Suez topic fell back to a low position among the other news items, e.g. taking fifth position in regular news.

iii. Topics: The reports' frequency displays the usual continual growth of the importance and awareness of crisis issues. First, the reports' focus was on debates, conferences or negotiations taking place behind closed doors, and there were reports about politicians arriving and departing during state visits. The next step of the narrative cycle was to display public protests, military mobilization, battles, and, subsequently, the consequences of war in a variety of ways. Finally, the reports turned to peace negotiations, again displaying the politicians arriving and departing, and, ultimately, the reports transition back to normality and the clean-up work on the canal. 
iv. Visual aesthetics and sound: Although foreign film material from the news agencies UP and Telenews was used, editors of Tagesschau selected and edited the material and added music and sound themselves, which makes it possible to define a certain, distinct Tagesschau style of 'reporting patterns.' The Tagesschau team had to work very quickly to produce daily news shows and as opposed to the weekly editions created by newsreels. The Tagesschau used hard cuts and fades in ring, edges or star shapes to separate the reports, in contrast to the relatively smooth transitions between one story to the next one found in newsreels. When it comes to sound, background music was orchestral or jazzy and did not fit to the visual elements properly. The active use of aural elements is another important difference between early television news and newsreels, since newsreel editors had the time and ability to match the music, sound, and pictures perfectly. Moreover, the music in the newsreels did not just function as background music, but it supported and dramatically enhanced the story. ${ }^{40}$ The Tagesschau editors however, had no time to match the aural and visual content. In the Tagesschau of 31 October 1956, the newscast followed a parade of Israeli military, which cut to a follow-up scene displaying a parade for Egyptian president Nasser. To allow the audience to separate the two parades, the camera focuses on signs or flags as national symbols. Those contrasting pictures and symbols enabled the audience to compare the parades, and to create an impression about the opponents.

\section{Frequency of the Reports of Suez Crisis}

From June 1956 to April 1957 Tagesschau broadcast 31 shows which included reports related to the Suez Crisis; mostly each show included one report about the Suez Crisis, but one report was often separated into two, three or four parts to cover different aspects. In the same period of time, 29 shows of Wochenspiegel were broadcast; seven of them included up to four reports related to the Suez topic (e.g. UN measures, state visits, consequences for oil supply, public reactions). ${ }^{41}$ On the whole, the reports in the Wochenspiege/ were not reproductions of Tagesschau-reports, but compilations of newer up-to-date reports. As the Wochenspiegel usually comprised compilations of the weeks' Tagesschau-stories, it must be asked why new stories were used. As the Tagesschau-reports had to be produced very quickly, it was not possible to include the films from abroad at the right time - it took at least one day to deliver the news films by plane from picture agencies. Thus, it is likely that the editors saved important reports for the Sunday show of Wochenspiegel.

Due to the frequency of reports, the 'career' of the topic is traceable. Reporting started on the 20 June 1956 with a report on the meeting between Soviet Foreign minister Sheplikow and Egypt's President Nasser about the offering of a multi-billion loan by the Soviets for the Aswan Dam project. The next report, broadcast in Wochenspiegel on 4 August, was on a Crisis Conference in Britain. From August to October 1956 Tagesschau reported just as unregularly, and weekly reports were provided by Wochenspiegel; but with the beginning of troop developments, end of October, and particularly at the peak of the conflict, from 10 to 15 November 1956, Tagesschau broadcast daily about the Suez case. The first report of active military engagement came up on 10 November 1956, and then the count of war reports began. Nearing the end of the crisis, end of March 1957, Tagesschau again increased their rate of reporting to nearly daily reports. Similar to modern news-making, a news issue is quickly forgotten when it is extended over a period of a few weeks, but the issues at hand gain momentum when there are new developments to the story or when the possibility of the conflict's solution becomes more likely.

Medial handling of the Suez Crisis issue is not only reflected by the frequency of reports, but also by the length of each of those reports. As one Tagesschau had approximately 20 minutes to deliver approximately ten reports, and one edition of Wochenspiegel had 30 minutes to deliver 15 to 20 reports, one report could have a length of one or two minutes. ${ }^{42}$ But at the peak of the crisis, with enough pictures and information available, the editor team compiled a report of 19 minutes only about the Suez Crisis for the 11 November 1956 edition of Wochenspiegel. Additionally, the Suez Crisis was also featured in the annual reviews of 1956 and 1957. In the 1956 review, the piece on the Suez 
Crisis fills about 12 minutes and covers the incidents between October and December. In the 1957 review, however, the resolution of the Suez Crisis in March had been covered for just about three minutes - although it covered the same period of three months' time. It seems that the conflicts were much more interesting or important than the positive aspects and solutions. The following graphs (Figure $4 a$ and Figure $4 b$ ) display the reports' frequency.

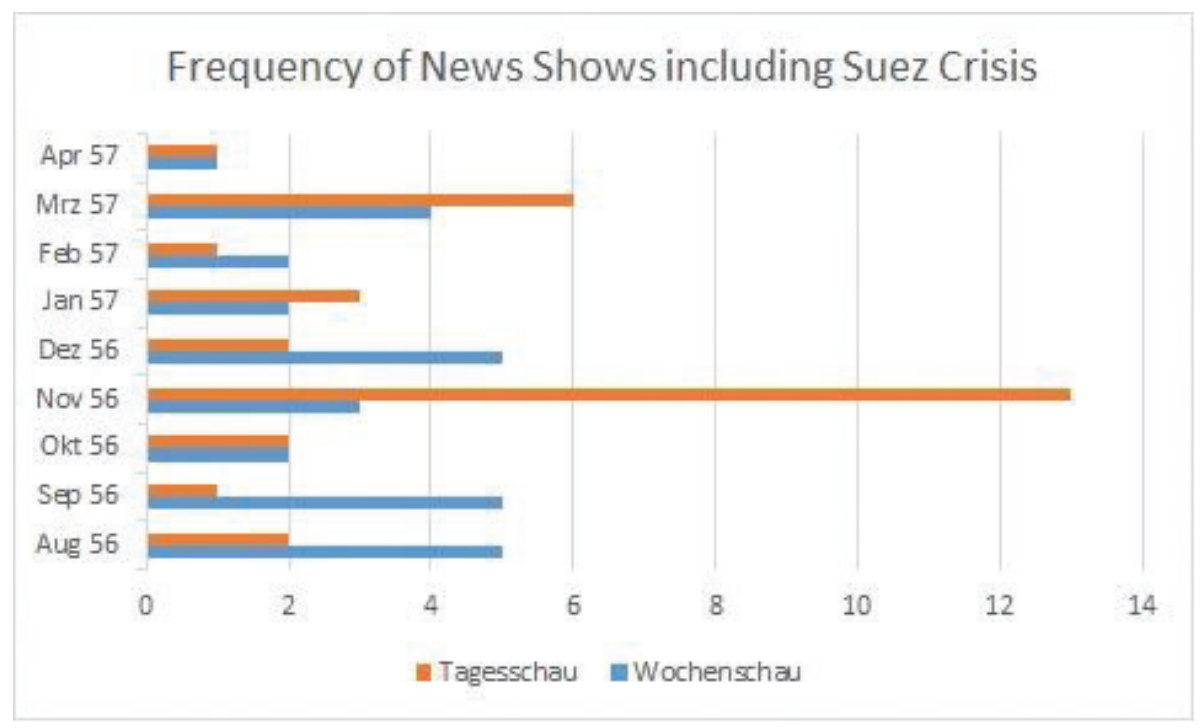

Figure 4a. Frequency of Suez Crisis-reporting in Television news.

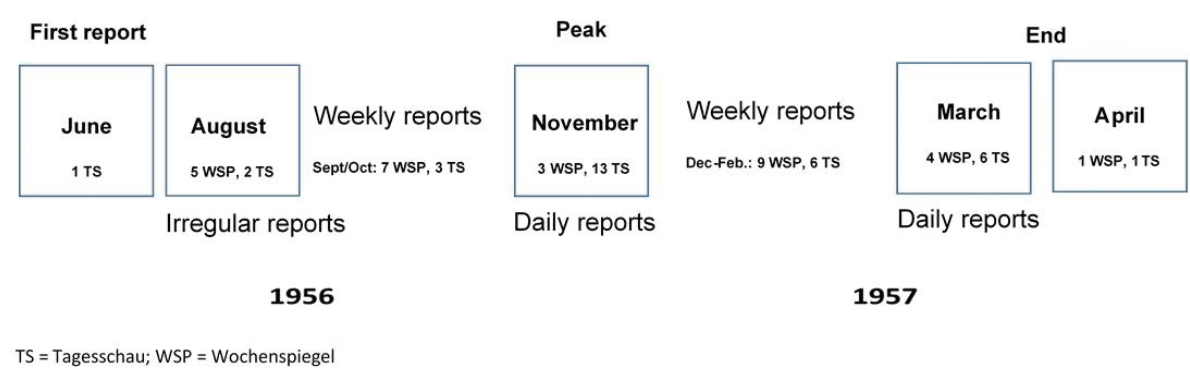

Figure 4b. Frequency of Suez Crisis-reporting as bar graph.

\section{Reports about the Suez Crisis: Examples}

In the following, examples of reports with pictures and text in chronological order are provided to highlight the earlierdescribed reporting style of the ongoing conflict. The report on 'Protests against the British Invasion,' contains original film-material from Germany. Tagesschau cameras filmed a demonstration in Hamburg against the war in the Middle East and 'the Invasion of Soviet troops in Hungary' and broadcast it together with other protests in America on 5 November 1956. ${ }^{43}$ The pictures reveal the cameraman's position among the protesters (see Figure 5), a position that a spectator presumably would have if they could have been there. The pictures show people of different nationalities, and above all one person wearing a traditional Arabic scarf. Protest banners show the protesters' demands such as "UNO erwache!" [UN awake!] and address an unambiguous request to the United Nations to stop the war. 


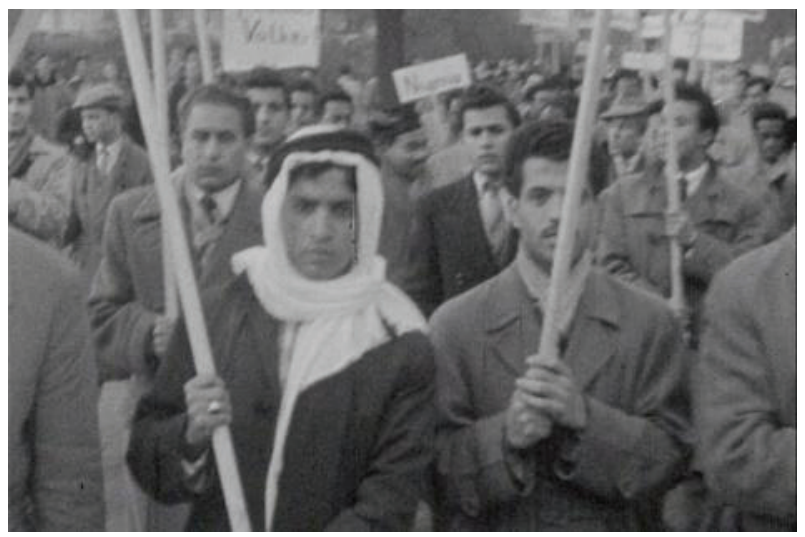

Figure 5. Protest and mourning for the incidents in Egypt and Hungary

At the peak of the conflict (just one and a half months later), cameramen took pictures directly by accompanying British soldiers in the Egypt city of Port Said. ${ }^{44}$ It is known from the text that civilians were sent from the streets when the house-to-house fights started (see Figure 6). So, the streets must have been empty. However, the film showed not only soldiers, but also injured civilians (see Figure 7). In the film, symbolic images were used - often-recurring visual metaphors for war and flight that are still used today, such as the images of walking feet that symbolize the suffering and misery of an invaded country and its people.
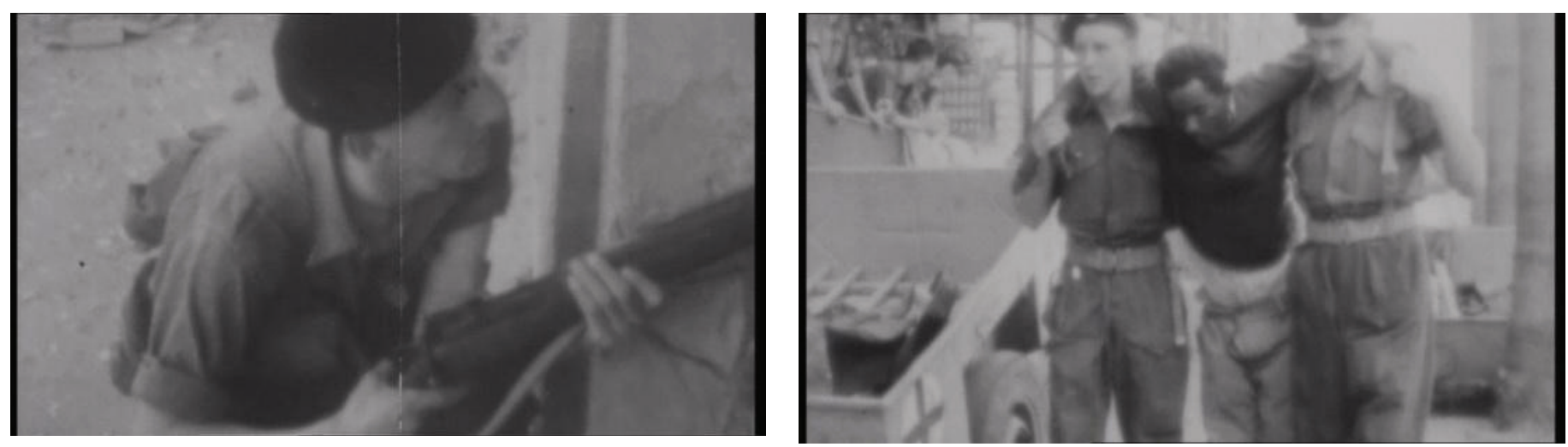

Figures 6 and 7: Shooting at a crisis hotspot.

Images of a refugee camp reveal not misery, but daily life by showing close-ups of women and children in a UNRWA-refugee camp (United Nations Relief and Work Agency) near the Gaza strip. The newsreader's text provides pieces of background information about the people on display: Arabs, who have fled from Palestine people isolated between frontiers who have lived in this camp for eight years. For the German audience, the exotic traditional clothes people were wearing, as well as the impressions of daily life in a UNRWA Camp, proved to be highly interesting. ${ }^{45}$ And again, since the cameramen filmed right from the centre of events, standing in the middle of a congregation of people (see Figure 8), the images gave the audience the impression of being there - almost participating in the events presented to them. 
S. Lehnert, The Suez Crisis of 1956 and 1957

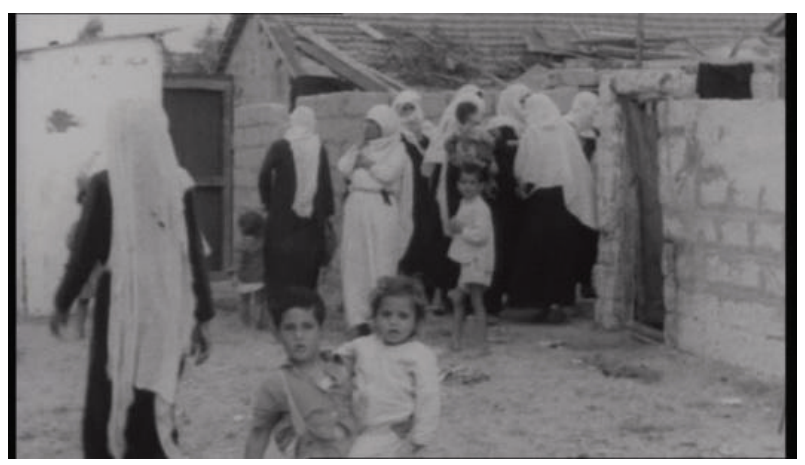

Figure 8. At the UNRWA Camp in Storebeach.

The Tagesschau not only reported on the war itself, but also on the activities surrounding the actual fights. Several pictures were taken from a bird's eye view and showed troop movements and similar activities, and cameramen often included camera-rides by car or plane in order to present a larger context. The 15 November 1956 report displayed a special form of imagery by application of hand cameras, a clear distinction from the newsreels, which generally used cameras on tripods for steady images ${ }^{46}$ : in those segments, the camera view wanders over rows of captured Egyptian tanks and missiles or it zooms in on particular details. In several shots, the camera begins with an exposition (long shot) and then zooms in via a medium long shot to finally zoom in to one particular detail with a close up shot on munitions boxes. The corresponding news-text explains that these captured Egyptian weapons are intended as supplies for Israeli troops. To secure transport routes for the captured weaponry, a railway segment had to be repaired - the camera shows the hard work in bright, hot sunlight. But among all these images of weapons and struggles (see Figure 9), some snippets also show civilian people, e.g. a woman carrying a basket (see Figure 10), or a soldier observing a young woman's notes, in order to provide an impression of daily life in such a situation.
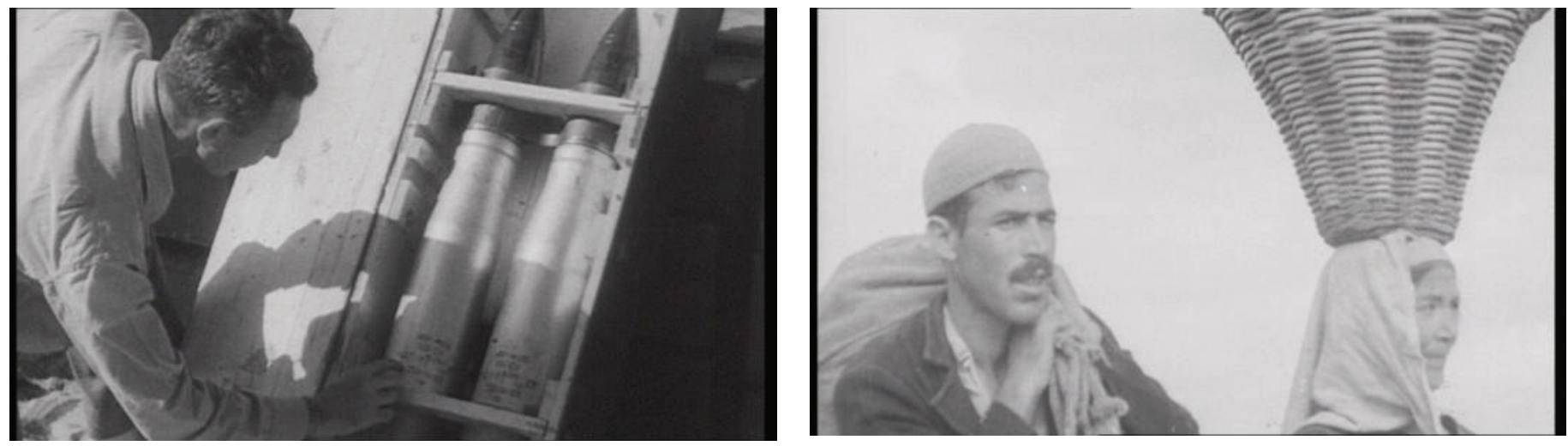

Figures 9 and 10. Captured Egyptian weapons and ammunition for Israel/ People as bystanders.

In the next example with pictures of the visit of the UNEF Commander, the Canadian Lt. General Burns, ${ }^{47}$ in Port Said, typical patterns of important people's arrival and departure are recognizable. A standard sequence of pictures is employed: impressions of an incoming plane followed by the Commander stepping onto the Gangway, shaking hands with representatives, cut to an opened car door, and the departing car, with the camera following the car. The corresponding news-text provides information about the Commander having arrived to inspect the troops during the clean-up process. In a second part of the report, troops are also shown during their leisure time (see Figure 11). These images do not display abstract political processes, but they offer the audience easy-to-understand content, which they could easily relate to from their TV-screens at home. Additionally, the images stressed the UN efforts in the crisis. The voice-over ${ }^{48}$ however, provides background information about Lt. General Burns' difficult situation, as Egypt demanded 
the withdrawal of Britain, France and Israel and threatened to involve voluntary armies deployed by the Soviet Union and China. These images show easy daily life, whereas the text reveals the difficulties inherent in the overall situation of the Suez Crisis.

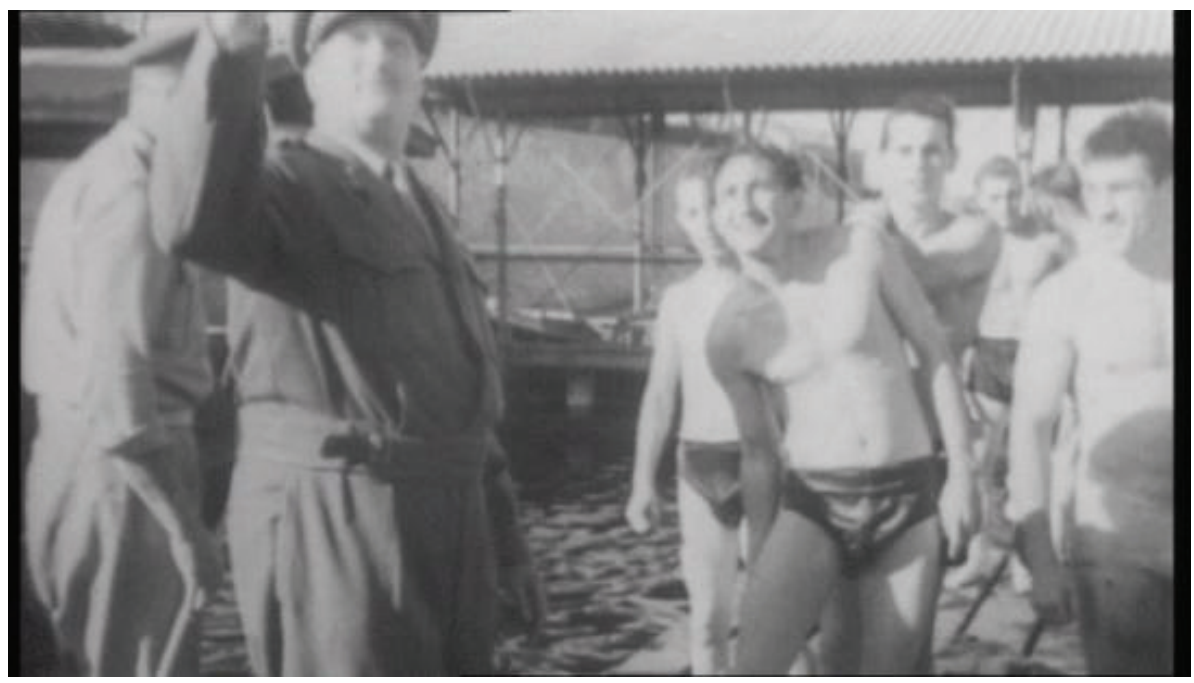

Figure 11. UNEF Commander in Egypt.

Between the conflict's peak and the alleviation of the situation, news topics included the consequences of an oil shortage in Europe and the withdrawal of French and British troops as well as the beginning stages of wreck removal operations in the canal. On 10 February 1957, Wochenspiegel reported that wreckage had been removed and that the Suez Canal was now free again for general shipping traffic. ${ }^{49}$ Contrasting with the news text, the film only shows the canal littered with wreckage, but no ships passing through the canal, indicating another information gap between text and images. The most interesting pictures for the German audience might have been those of the operation of the two German ships.

What is interesting in this case, is the fact that the cameraman must have been on board of one of those ships in order to take close-ups of jacks and ropes that were used to move and get rid of the wreckage (see Figure 12). As the flags of those nations that could use the canal again were displayed, the audience could well imagine the importance of restored freedom and peace. In this case, the background music used for the report has been preserved as well: accompanying the film, a selection of Jazz music is constantly playing. In the late 1950s, jazz music gain more and more acceptance as music for modern and intellectual people. ${ }^{50}$ Through the use of jazz, the Tagesschau has been able to present itself as a modern and serious medium.

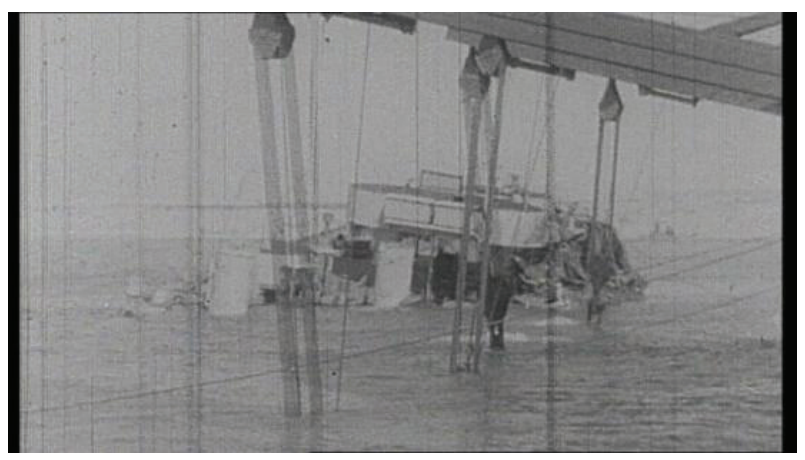

Figure 12. Suez Canal passable again. 
For the German audience, the best way to get a summarized view and impression of the Suez Crisis might have been the annual reviews, which were broadcast around 30 December each year. The 1956 review began with an impression of the canal that then changed into a flashback of the crisis' peak in October 1956. Then the story behind the crisis and the most important milestones and stations of the conflict were narrated. The 1957 review just dealt with one issue: German ships that helped with the wreckage disposal in the canal - now also displaying regular shipping traffic as a result of the clean-up operation.

\section{Conclusion}

The Suez Crisis case shows that the news factors defined by journalism research in the $1960 \mathrm{~s}^{51}$ proved to be reliable: actuality, impact, proximity, the bizarre, conflict, currency and human interest. All of these news factors apply in the case of the Suez Crisis and influenced the reporting frequency as well as way of reporting. Compared to the weekly cinema newsreels, the images brought to West German audiences via television may not have been as impressive because the cinematic atmosphere was missing, but the television images were much more vivid (e.g. through the use of hand cameras, zooms, live broadcasts and voices that addressed the families at home). They brought 'normal' daily life of those involved in the crisis into living rooms and made audiences feel like they were actually attending a historical event. To conclude, one might summarize that, on the one hand, war-reporting patterns did not change since many of the ways news reports frame their content, are still used in modern television news. But on the other hand, reports on wars and conflicts have always favoured the development of the media. History shows that the media was always supported by governments when broadcasting information that was needed, e.g. the demand of networks increased in wartime ${ }^{52}$ or to present military success, e.g. colored monthly newsreels were produced in the Second World War. ${ }^{53}$ And it seems that particularly through the advancements in war reporting (and broadcasting in general), Tagesschau became the serious and credible show ${ }^{54}$ we know today.

\section{Notes}

1. Knut Hickethier, Geschichte des deutschen Fernsehens [History of German Television] (Stuttgart: J.B. Metzeler, 1998$), 175$.

2. Ibid., 177.

3. Jan Thilo Haux worked for the West German newsreel Welt im Film until 1952, in 1953 he joined the Tagesschau team, cf. Jürgen Lossau, "Der Kameramann Jan Thilo Haux" [The Cameraman Jan Thilo Haux], Film- und Fernsehmuseum Hamburg e.V.: Jan Thilo Haux (filmmuseum-hamburg.de)

4. Television was set up at Nordwestdeutscher Rundfunk [Northwest German Broadcasting] (NWDR) in Hamburg. In 1950, the NWDR television broadcasts the first television picture in Germany after the Second World War (test picture).

5. Martin S. Svoboda, "Vom Standfoto zur ,Tagesschau" [From the still photo to the ,Tagesschau"], in Zweimal Deutschland seit 1945 im Film und Fernsehen I: Von der Kinowochenschau zum aktuellen Fernsehen [Twice Germany since 1945 in Film and Television I: From the Cinema Newsreel to Contemporary Television], eds. Karl-Friedrich Reimers, Monika Lerch-Stumpf and Rüdiger Steinmetz (München: Ölschläger, 1983), 135.

6. Letter from Martin S. Svoboda to Intendant Werner Pleister, September 14, 1953, subject: „Lernen's die Kölner nie?“ [Don't the colleagues in Cologne ever learn?] Tagesschau vom Sonnabend, dem 12.9.1953, NWDR-Bestand (621-1-144), 194 Technische, finanzielle, inhaltliche Probleme der Tagesschau, Staatsarchiv Hamburg.

7. Elisabeth Noelle and Erich Peter Neumann, eds., Jahrbuch der öffentlichen Meinung 1957 [Yearbook of Public Opinion 1957] (Allensbach: Verlag für Demoskopie), 83, based on a survey of 1956, representative sample of 2000 persons (FRG and West Berlin).

8. Ibid., 88-89.

9. Cf. Patrick Uhe, Vom Kellerkind zur Institution: Die "Tagesschau”, 2012, https://www.ndr.de/der_ndr/unternehmen/chronik/ Vom-Kellerkind-zur-Institution-die-Geschichte-der-Tagesschau,ardaktuell101.html.

10. According to broadcast protocols of Tagesschau. 
11. Letter from Harold Cox, Television Newsreel Manager BBC to Svoboda (translated), from March 19, 1953, NWDR-Bestand (621-1-144), 194 Technische, finanzielle, inhaltliche Probleme der Tagesschau, Staatsarchiv Hamburg.

12. It originates from the composition Hammond-Fantasie by Hans Carste and was arranged for the radio orchestra by Rudolf Kühn, Documentary "Vom Kellerkind zur Primadonna" [From basement child to prima donna], June 4, 1990, NDR.

13. Which are standards today, cf. Heinz Bonfadelli, Medien und Gesellschaft im Wandel, 2016, https://www.bpb.de/ gesellschaft/medien-und-sport/medienpolitik/236435/medien-und-gesellschaft-im-wandel.

14. Tagesschau-Jahresrückblick 1956 [annual review from 1956], https://www.tagesschau.de/multimedia/video/ jahresrueckblick/1956/video793476.html.

15. Tagesschau F: 565, 24/9 1956, “Nichts Neues am Suezkanal” [Nothing new on the Suez Canal] (0’53), Fernseharchiv NDR, Hamburg.

16. Cinema newsreels existed in Germany since the 1910s.

17. For further information about relationship between Neue Deutsche Wochenschau and Tagesschau as well as development of news broadcasting, cf. Sigrun Lehnert, Wochenschau und Tagesschau in den 1950er Jahren [Newsreel and Tagesschau news in the 1950s] (Konstanz, UVK, 2013).

18. Cf. Svoboda, Standfoto zur Tagesschau, 123-140.

19. Cf. Horst Jaedicke, Tatort tagesschau [Crime scene Tagesschau] (München, Allitera, 2002), 204.

20. Cf. statistics, http://www.fernsehmuseum.info/fernsehzuschauer-statistiken.html. At the same time, cinema audience numbers decreased from 818 million in 1956 to 605 million in 1960 (in 1965, 320 million were left); with the effect that the number of cinemas decreased as well (from 6438 in 1956 to 5209 in 1965); cf. ARD, Rundfunkanstalten und Tageszeitungen. Untersuchungsergebnisse und Empfehlungen [Broadcasters and Daily Newspapers. Research results and Recommendations] (Mainz: v. Hase \& Koehler, 1969), 5-6.

21. Noelle and Neumann, Jahrbuch der öffentlichen Meinung 1957, 8.

22. Hans-Joachim Reiche, Veteran auf dem Bildschirm. Fünfzehn Jahre Tagesschau, in Logoluis, Christian, ed., Fernsehen in Deutschland. Gesellschaftspolitische Aufgaben und Wirkungen eines Mediums [Television in Germany. Socio-political Tasks and Effects of a Medium] (Mainz: v. Hase und Koehler, 1967), 121.

23. Hickethier, Geschichte des deutschen Fernsehens, 177.

24. Noelle and Neumann, Jahrbuch der öffentlichen Meinung 1957, 82-83.

25. Ibid., 105.

26. Reiche, Veteran auf dem Bildschirm, 120.

27. Ibid.

28. Cf. Ulrich Pfeil, "Die Suezkrise," in Das Krisenjahr 1956. Aus Politik und Zeitgeschichte [The crisis year 1956. From politics and contemporary history] (Bonn: Bundeszentrale für politische Bildung, 2006), 32-38.

29. Ibid.

30. BBC Documentary The Other Side of Suez, 2004

31. Anonymous, "Die Lotsen Jagd" [The Pilot Hunt], Der Spiegel, 36, September 5, 1956, 28-30.

32. BBC Documentary, The Other Side of Suez.

33. Cf. Pfeil, Die Suezkrise.

34. Ibid.

35. BBC Documentary The Other Side of Suez.

36. Both German states fought for being the one and only German state (Alleinvertretungsanspruch), cf. Pfeil, Die Suezkrise.

37. A presenter personally appeared for the first time on-screen on 2 March 1959. A presenter (Karl-Heinz Köpcke, Diether von Sallwitz) read the news in a 5-minutes-block, followed by 15 minutes of film material. On 1 December 1960, the alternation of film and textual reports was introduced - this way of presentation is still used.

38. Information on the text sheets, preserved at ARD aktuell, NDR Hamburg.

39. E.g. Text of Wochenspiege/ F: 177, 8/9 1956 (as an exception on a Saturday), Text of Wochenspiege/ F: $178,16 / 9$ 1956.

40. Cf. Sigrun Lehnert, "Ursprung und Entwicklung der Musik in der Wochenschau. Muster, Funktionen und Kontinuitäten vom Stummfilm bis zur Tagesschau" [The origin and development of music in newsreels. Patterns, functions and continuities from silent film to the newsreel], Nach dem Film No. 14, Audio History, December 6, 2014, https://www.nachdemfilm.de/issues/ text/ursprung-und-entwicklung-der-musik-der-wochenschau.

41. Research in Television Archives of Norddeutscher Rundfunk (NDR) in Hamburg, in February 2013 by the author on basis of the extract of the archives delivered by Fernseharchiv NDR.

42. A newsreel usually delivered ten reports in ten minutes - but due to the longer production frequency of weekly editions, newsreels had more time for editing and matching music, pictures, sound, and text.

43. Tagesschau F: 598, 5/11 1956, "Proteste und Trauerfahnen zu den Ereignissen in Ungarn und Nahost" [Protests and funeral banners on the events in Hungary and the Middle East] (1'58), Fernseharchiv NDR, Hamburg.

44. Tagesschau F: 604, 12/11 1956, "Schießerei im Krisengebiet" [Shooting in Crisis Area] (0’47), Fernseharchiv NDR, Hamburg.

45. Tagesschau F: 604, 12/11 1956, "Flüchtlingslager am Gaza Streifen“ [Refugee camp in the Gaza Strip] (1'24), Fernseharchiv NDR, Hamburg. 
46. Tagesschau F: 607, 15/11 1956, "Ägyptische Beutewaffen für Israel, Bahnlinie wird ausgebessert" [Egyptian prey weapons for Israel, railway line is being repaired] (1'48), Fernseharchiv NDR, Hamburg.

47. Tagesschau F: 619, 30/11 1956, "Oberbefehlshaber der UNO-Polizeitruppen in Ägypten" [Commander-in-Chief of the UN police forces in Egypt] (1'50), Fernseharchiv NDR, Hamburg.

48. Text of Tagesschau F: 619, 30/11 1956, ARD aktuell NDR, Hamburg.

49. Wochenspiegel F: 198, 10/2 1957, “Ägypten: Suezkanal wieder befahrbar“ [Egypt: Suez Canal passable again] (0’58), Fernseharchiv NDR, Hamburg.

50. Cf. Bernd Hoffmann, "Eisgekühlter Hot" [Ice-cooled Hot], Kieler Beiträge zur Filmmusikforschung [Kiel Contributions to Film Music Research], 12/2016, 395-431, 396.

51. E.g. Johan Galtung, and Mari H. Ruge, "The Structure of Foreign News. The Presentation of the Congo, Cuba and Cyprus Crisis in Four Norwegian Newspapers," Journal of Peace Research 2, no. 1 (1965): 64-90.

52. Cf. Knut Hickethier, Einführung in die Medienwissenschaft [Introduction to Media Studies] (Stuttgart, J.B. Metzler, 2003$), 311$.

53. Cf. Hans-Peter Fuhrmann, Die Panorama-Monatsschau 1944/45. Erschließung und kritische Filmanalyse, [The Panorama Monthly Show 1944/45. Indexing and Critical Film Analysis] (Weimar: Verlag und Datenbank für Geisteswissenschaften, 2010).

54. Cf. Joachim Drengberg, "Die Tagesschau der fünfziger Jahre. Auf dem Weg zu einer täglichen Nachrichtensendung” [The Tagesschau of the fifties. On the way to a daily news programme], Mitteilungen des Studienkreises Rundfunk und Geschichte 12, no. 2 (1986): 128-139. Interview with the former Tagesschau-editor Jaedicke: from 1955 to 1957 the idea of sensible editing ("der redaktionelle Gedanke") was developed in TV news reporting.

\section{B i o graph y}

Dr. Sigrun Lehnert is is a media scholar in Hamburg. She earned her PhD with a work on "Wochenschau und Tagesschau in den 1950er Jahren" (about transitions from cinema to early post-war television) at the University of Hamburg. The following book has been published in 2013 by UVK Verlag, Konstanz. In her post-doc project, she compares among others West and East German newsreels. Her research interests are film and television history, newsreels, documentary film, archiving, and film heritage. 